\title{
The general characteristics and organic matters of therapeutic mud from Lake Noot (Mongolia)
}

\author{
Ganzaya Gankhurel”, Nomintsetseg Byambajav, Bayaraa Batnasan, Dolmaa Gania*
}

Institute of Chemistry and Chemical Technology, Mongolian Academy of Sciences, Ulaanbaatar 13330, Mongolia

\author{
*Corresponding author: ganzaya_g@mas.ac.mn; ORCID ID: 0000-0003-3919-8475 \\ ${ }^{* *}$ Deceased
}

Received: 10 January 2021; revised: 5 July 2021; accepted: 6 July 2021

\begin{abstract}
In this investigation, we examined the chemical composition, physicochemical properties, and organic matter of therapeutic mud from Lake Noot in the Arkhangai province of Mongolia. The therapeutic mud from Lake Noot is used in the pelotherapy of local health care services for some time but without deep characterization. Due to this, a study of therapeutic mud samples was required. Our research concentrated on identifying general characteristics, organic matter, mineralogical, and chemical composition of therapeutic mud at two different Lake Noot sites. Results showed that the therapeutic mud belongs to the continental hydrogen sulfide sticky mud type. The total organic matter in the therapeutic mud of Lake Noot was $14.44 \%$. Total organic matter contains a humic substance of $42.17 \%$, lipid $16.62 \%$, and carbohydrate $7.13 \%$. A total of 172 compounds were identified in the dissoluble organic matter of therapeutic mud, mainly of natural origin, using the gas chromatography-mass spectrometry (GC/MS) method. The dominant compounds were saturated and unsaturated hydrocarbons with 13 - 44 carbon atoms and carboxylic acids and their ethers. Some of the identified organic compounds have been reported antimicrobial, anti-inflammatory, antibacterial, and antifungal properties.
\end{abstract}

Keywords: humic substance, organic matter, lake, lipid, sticky mud

\section{INTRODUCTION}

Since ancient times humanity has used therapeutic mud; however, we did not utterly understand its composition and properties until the nineteenth century. Back then, countries have been intensively studied the composition and biological activity of therapeutic mud in their respective territories. Lately, there were many studies worldwide to determine the essential physicochemical characteristics of therapeutic muds in various spa centers [1-3]. Mongolian scientists started research in this field in the 1950s; however, mineral spring's research has developed, and therapeutic muds study was abandoned. Mongolia is a Central Asian country with an extreme continental climate. It has a remarkable abundance and variety of lakes, some large enough to be classified among Eurasia's largest [4]. In Mongolia, natural therapeutic muds used in pelotherapy are abundant, and people used them in traditional medicine to treat pains. However, the exact composition of therapeutic mud is less studied. In this study's framework, analyses were carried to assess Lake Noot's therapeutic mud suitability for therapeutic use. This report aims to determine the chemical composition, physicochemical properties, and some organic compounds of natural therapeutic mud from Lake Noot in Mongolia's Central region. The study of therapeutic mud from Lake Noot is part of a project to characterize Mongolian therapeutic mud deposits [5]. Result of this research is expected to increase local spacenters' opportunities to engage in entrepreneurship of medical tourism uses natural resources.

\section{EXPERIMENTAL}

Sampling area and material: Lake Noot (geographic coordinates $99^{\circ} 49^{\prime} \mathrm{E} ; 48^{\circ} 07^{\prime} \mathrm{N}$ ) is located in Tariat soum of Arkhangai province in the Central region of Mongolia. Lake Noot is at an altitude of $2064 \mathrm{~m}$ and has a surface area of about 211 ha with a length of $2.2 \mathrm{~km}$, a width of $1.7 \mathrm{~km}$, an average depth of $3.5 \mathrm{~m}$, and a volume of 2.9 million $\mathrm{m}^{3}$ [6]. Therapeutic mud samples were collected from 2 different parts (southeast 99 52 'E; $48^{\circ} 07^{\prime} \mathrm{N}$ and southwest $99^{\circ} 51^{\prime} \mathrm{E}$; $48^{\circ} 06^{\prime} \mathrm{N}$ ) of Lake Noot. Samples were taken from 2 sites in the southwestern and southeastern Lake Noot (Fig. 1). Samples (in $20-40 \mathrm{~cm}$ depth) were collected by the hand-driven sampler (7.5 $\mathrm{cm} \times 60 \mathrm{~cm}$ ) and sealed in glass containers of $1000 \mathrm{ml}$. 
The sediment samples were placed in a cooler at $4{ }^{\circ} \mathrm{C}$ and transported to the laboratory.

General characteristics: The general characteristics (density, moisture, heat capacity, Etc.) of therapeutic mud were determined by the Shukarev method [7].

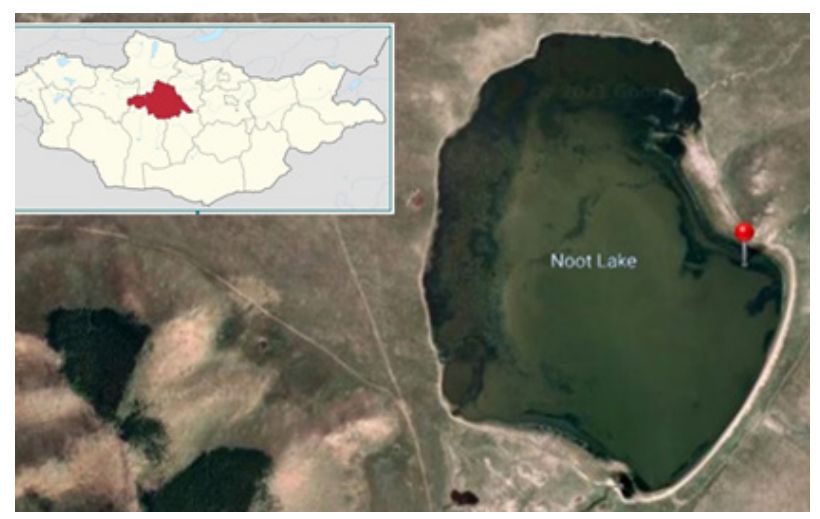

Fig. 1. The study area of Lake Noot, Tariat soum, Arkhangai province

The concentration of total organic carbon (TOC) was analyzed by the Tyurin method [8]. This method is based on the oxidation of organic matter with chromic acid to form carbon dioxide. The quantity of oxygen consumed for the oxidation of organic carbon is determined by the difference between the amount of chromic acid taken for oxidation and its remaining unused after oxidation. Hydrogen sulfide in samples was determined by oxidation with $0.1 \mathrm{~N}$ iodine solution. $\mathrm{H}_{2} \mathrm{~S}$ was purged by carbon dioxide from the samples while acidifying with $10 \% \mathrm{HCl}$ and trapped in an iodine solution. 0.1 $\mathrm{N}$ sodium thiosulfate was used as the titrating. The concentration of total organic matter (TOM) was evaluated by the next equation.

$$
\mathrm{TOM}=\mathrm{TOC} \times 1.72
$$

Mineralogical and chemical composition: The mineralogical composition, organic component, and chemical composition were determined by preparing a mixture (1:1) of two samples. The mineralogical composition was determined by X-ray diffraction (XRD) using a SHIMADZU MAXima-X XRD-7001 $\mathrm{X}$-ray instrument with $\mathrm{Cu} \mathrm{Ka}$ radiation. Analyses were performed in a $2 \theta$ range of 10 to $80^{\circ}$ at a scan rate of $0.02^{\circ} \mathrm{s}^{-1}, 30 \mathrm{~mA}$ of current intensity, and $40 \mathrm{kV}$. The major elements were determined by $X$-ray fluorescence analysis (XRF), using the Axios Max equipment. The concentrations of minor elements were determined by inductively coupled plasma-optical emission spectrometry (ICP-OES) using the Agilent ICP-OES 5110 equipment. All the analytical work was conducted at the laboratories of the ALS geochemistry laboratory.

Determination of organic components: The organic components were extracted from dried therapeutic mud that preliminary washed with distilled water to clean from salts and air-dried. The lipid fraction was extracted by a mixture of chloroform / ethanol (1:1) [9].
The humic substance was extracted with $0.2 \mathrm{~N} \mathrm{NaOH}$ after the demineralization by $10 \%$ hydrochloric acid. Carbohydrates were extracted by water at $40-50{ }^{\circ} \mathrm{C}$ and purified using dialysis bags [10]. Free organic components were extracted using the Soxhlet apparatus, and Soxhlet extraction was performed with different solvents such as hexane, chloroform, acetone, and a mixture of ethanol / benzene (1:9). The solvents were evaporated by a rotary vacuum evaporator [11]. The extracted fractions were mixed and dissolved in chloroform. Dissolved organic matter (DOM) in chloroform was analyzed using gas chromatographymass spectrometry (GC/MS).

Gas chromatography-mass spectrometry analysis (GC-MS): Gas Chromatography-Mass Spectrometry was performed using Thermo Scientific GC (Trace 1310) - MS (TSQ 8000). The GC-MS was fitted with a $30 \mathrm{~m}$ Agilent fused capillary column, DB- $5 \mathrm{~ms} 0.25 \mathrm{~mm}$, $0.25 \mathrm{mkm}$ Film - initial temp $50{ }^{\circ} \mathrm{C}$ held for $1 \mathrm{~min}$, then programmed at $8{ }^{\circ} \mathrm{C} / \mathrm{min}$ ramp to $300^{\circ} \mathrm{C}$, the isothermal temperature was held for $30 \mathrm{~min}$. The injection port temperature was $250{ }^{\circ} \mathrm{C}$, and $1 \mu \mathrm{L}$ volume was injected into a splitless mode. Helium was used as a carrier gas at a constant flow of $1.5 \mathrm{~mL} / \mathrm{min}$, head pressure 9.10 psi. The mass spectrometer was operated in an electron ionization mode with ion source temperature at $250{ }^{\circ} \mathrm{C}$. The organic compounds were identified by comparing chemical software, and databases were used to analyze the results MS Windows NIST Mass Spectral, NIST (NIST21, NIST 98).

\section{RESULTS AND DISCUSSION}

General characteristics of therapeutic mud from Lake Noot: We determined the general characteristics of therapeutic mud at two sites of Lake Noot (Table 1). The investigated therapeutic muds were a sticky mass of dark gray color with a light smell of hydrogen sulfide. The moisture amount of $100 \mathrm{~g}$ natural clay was $39.56-40.38 \%$.

Table 1. General characteristics of therapeutic mud

\begin{tabular}{|c|c|c|c|}
\hline \multirow[t]{2}{*}{$\begin{array}{l}\text { General } \\
\text { characteristics }\end{array}$} & \multicolumn{2}{|c|}{$\begin{array}{c}\text { Therapeutic mud of } \\
\text { Lake Noot }\end{array}$} & \multirow{2}{*}{$\begin{array}{l}\text { Hydrogen } \\
\text { sulfide sticky } \\
\text { mud }\end{array}$} \\
\hline & Southeast & Southwest & \\
\hline Color & Dark gray & Dark gray & Dark gray \\
\hline $\mathrm{pH}$ & 8.2 & 8 & $7.0-9.7$ \\
\hline Moisture, \% & 40.38 & 39.56 & $40-61$ \\
\hline Density, g/cm3 & 1.33 & 1.40 & $1.1-1.6$ \\
\hline $\begin{array}{l}\text { Admixture } \\
\text { (more than }>0.25 \\
\text { mm diameter) }{ }^{*}, \%\end{array}$ & 25.59 & 29.64 & - \\
\hline $\mathrm{TOC}^{*}, \%$ & 8.5 & 8.3 & $1-15$ \\
\hline $\mathrm{H}_{2} \mathrm{~S}^{*}, \%$ & 0.12 & 0.09 & $0.05-0.5$ \\
\hline $\begin{array}{l}\text { Heat capacity, } \\
\mathrm{cal} / \mathrm{g} \text { grad }\end{array}$ & 0.84 & 0.51 & - \\
\hline
\end{tabular}

Note: *- in dry weight

The amount of moisture relates to such properties as mud heat capacity, plasticity, and density. The 
therapeutic mud has multiple admixtures with a diameter of more than $0.25 \mathrm{~mm}(25.59-29.64 \%)$, and it impossible to use directly for treatment. Therefore, after cleaning of admixtures possible to use for treatment. According to Malakhov and Ivanov's classification (Table 2) [12], based on mud's properties, we classified Lake Noot mud as a hydrogen sulfide sticky mud.

Table 2. Classification of therapeutic mud [12]

\begin{tabular}{lllll}
\hline \multirow{2}{*}{ Group } & \multicolumn{3}{c}{ Sticky mud } & Volcanic \\
\cline { 2 - 4 } & Sapropel & $\begin{array}{l}\text { Hydrogen } \\
\text { sulfide }\end{array}$ & Peat & Vown, dark, \\
\hline Color & $\begin{array}{l}\text { Gray, dark, } \\
\text { brown, dark gray }\end{array}$ & $\begin{array}{l}\text { Dark, } \\
\text { gray }\end{array}$ & $\begin{array}{l}\text { Brown } \\
\text { dark brown }\end{array}$ & Gray \\
Moisture, \% & $80-95$ & $40-61$ & $60-80$ & $20-50$ \\
$\begin{array}{l}\text { Density, } \\
\text { g/cm }\end{array}$ & $1.005-1.15$ & $1.1-1.6$ & $1.01-1.5$ & - \\
$\mathrm{pH}$ & $6.6-7.5$ & $7.0-9.7$ & 2.8 & 5.0 \\
$\mathrm{H}_{2} \mathrm{~S}^{*}$ & $0.01-0.05$ & $0.05-0.5$ & $<0.05$ & 0.02 \\
$\mathrm{TOC}^{*}$ & $15-90$ & $1-15$ & $20-98$ & $<0.5$ \\
\hline
\end{tabular}

Note: *- in dry weight

Mineralogical and chemical composition of therapeutic mud from Lake Noot: The mineralogical analysis results are shown in Table 3 and Figure 2 . The mineralogical analysis of therapeutic mud from Noot Lake showed substantial amounts of primarily carbonate minerals (calcite) and albite, while quartz and anorthite were also determined.

Table 3. Mineralogical composition in therapeutic mud from Lake Noot

\begin{tabular}{lllll}
\hline Minerals & Albite & Anorthite & Calcite & Quartz \\
\hline Mineral class & Silicates & Silicates & Carbonates Silicates \\
Group & Feldspar & Feldspar & Calcite & Quartz \\
Formulas & $\mathrm{NaAlSi}_{3} \mathrm{O}_{8}$ & $\mathrm{CaAl}_{2} \mathrm{Si}_{2} \mathrm{O}_{8}$ & $\mathrm{CaCO}_{3}$ & $\mathrm{SiO}_{2}$ \\
Content, \% & 31.75 & 4.12 & 53.13 & 11.00 \\
\hline
\end{tabular}

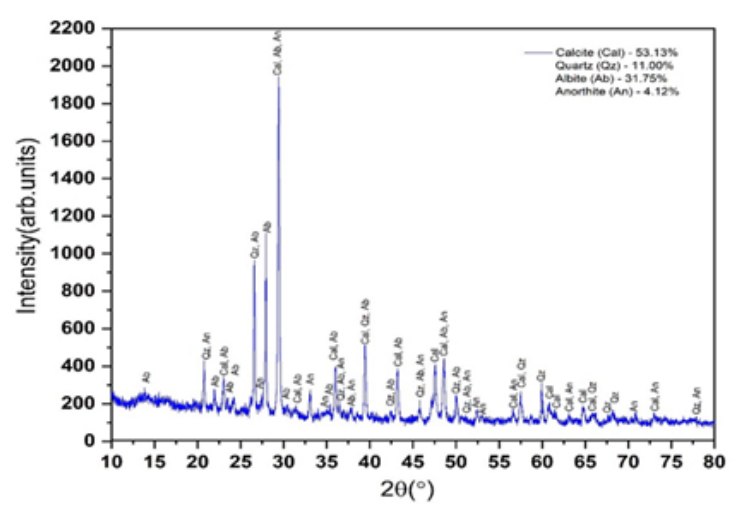

Fig. 2. XRD pattern of therapeutic mud from Lake Noot

The major and trace element composition is presented in Table 4, and the results are compared with the ranges of the continental crust [13].

The elements are divided into four groups in accordance with their biological effect: (I) elements with a specific pharmacological effect $\mathrm{Fe}, \mathrm{Co}, \mathrm{J}, \mathrm{Br}$, and $\mathrm{B}$, optionally;
(II) elements involved in the enzymatic processes in the body J, Fe, $\mathrm{Cu}, \mathrm{Mo}, \mathrm{Zn}, \mathrm{Co}, \mathrm{Mn}$ as well as $\mathrm{Ni}, \mathrm{Ba}, \mathrm{Sr}$, Cd possibly; (III) elements which are toxic to humans including $\mathrm{As}, \mathrm{Pb}, \mathrm{Hg}, \mathrm{V}$, and $\mathrm{F}$; (IV) elements of which biological role is not yet elucidated including $\mathrm{Ti}, \mathrm{Zr}$, Jr, Cs, and many others [14]. According to the results of the chemical composition analysis, it can be seen that the concentrations of major and trace elements in Noot therapeutic mud within the minor elements in the therapeutic mud were $\mathrm{Ba}$ (510 ppm) and $\mathrm{Sr}$ (871 ppm). The high amount of $\mathrm{Sr}$ in the elements of therapeutic mud is due to the high content of $\mathrm{CaO}$ and the association of Sr with the calcite in lake sediments [15].

Table 4. Chemical composition of the therapeutic mud

\begin{tabular}{|c|c|c|}
\hline Elements & Therapeutic mud & Continental crust \\
\hline \multicolumn{3}{|c|}{ Major elements, $\%$} \\
\hline $\mathrm{SiO}_{2}$ & 33.11 & 60.6 \\
\hline $\mathrm{TiO}_{2}$ & 0.28 & 0.72 \\
\hline $\mathrm{Al}_{2} \mathrm{O}_{3}$ & 6.79 & 15.9 \\
\hline $\mathrm{Fe}_{2} \mathrm{O}_{3}$ & 1.87 & 6.71 \\
\hline $\mathrm{MnO}$ & 0.08 & 0.1 \\
\hline $\mathrm{MgO}$ & 1.16 & 4.66 \\
\hline $\mathrm{CaO}$ & 21.9 & 6.41 \\
\hline $\mathrm{Na}_{2} \mathrm{O}$ & 1.64 & 3.07 \\
\hline $\mathrm{K}_{2} \mathrm{O}$ & 1.56 & 1.81 \\
\hline $\mathrm{P}_{2} \mathrm{O}_{5}$ & 0.12 & 0.13 \\
\hline \multicolumn{3}{|c|}{ Minor elements, ppm } \\
\hline $\mathrm{Ag}$ & $<0.5$ & 56 \\
\hline As & 11 & 2.5 \\
\hline $\mathrm{Ba}$ & 510 & 456 \\
\hline $\mathrm{Be}$ & 1 & 1.9 \\
\hline $\mathrm{Bi}$ & $<2$ & 0.18 \\
\hline $\mathrm{Cd}$ & $<0.5$ & 0.08 \\
\hline Co & 4 & 26.6 \\
\hline $\mathrm{Cr}$ & 17 & 135 \\
\hline $\mathrm{Cu}$ & 8 & 27 \\
\hline $\mathrm{Ga}$ & $<10$ & 16 \\
\hline $\mathrm{La}$ & 10 & 20 \\
\hline Mo & 3 & 0.8 \\
\hline $\mathrm{Ni}$ & 5 & 59 \\
\hline $\mathrm{Pb}$ & 14 & 11 \\
\hline $\mathrm{Sb}$ & $<5$ & 0.2 \\
\hline Sc & 3 & 0.08 \\
\hline $\mathrm{Sr}$ & 871 & 320 \\
\hline Th & $<20$ & 5.6 \\
\hline $\mathrm{TI}$ & $<10$ & 0.5 \\
\hline$U$ & $<10$ & 1.3 \\
\hline V & 19 & 138 \\
\hline W & $<10$ & 1 \\
\hline $\mathrm{Zn}$ & 26 & 72 \\
\hline
\end{tabular}

Organic matter in therapeutic mud from Lake Noot: According to Suarez. M et al, "Therapeutic muds are a typical example of natural products that contain organic compounds with biological activity, which allows their use in the treatment of different pathologies" [16]. Therapeutic mud contains various organic matters, such as lipid, humic substances, carbohydrates, and 
free and mineral - associated organic matter (associated with silicate, carbonate, and sulfide minerals). TOM content, as estimated from TOC content, was $14.4 \%$ in dry weight. TOM comprises a humic substance of $42.17 \%$, lipid $16.62 \%$, and carbohydrate $7.13 \%$. The extraction results of free organic matter have shown in Table 5. The free organic matter was more extracted by hexane than other solvents. This result indicates that free organic matter contained highly non - polar organic compounds.

Table 5. Free organic matter of therapeutic mud

\begin{tabular}{llll}
\hline \multirow{2}{*}{ Solvents } & \multirow{2}{*}{$\begin{array}{c}\text { Extraction } \\
\text { time, } \mathbf{h}\end{array}$} & \multicolumn{2}{c}{ Yield, \% } \\
\cline { 3 - 4 } & 11 & 0.57 & 3.92 \\
\hline Hexane & 7 & 0.48 & 3.32 \\
Chloroform & 12 & 0.12 & 0.81 \\
Acetone & 11 & 0.54 & 3.73 \\
Ethanol/Benzene (1:9) & 41 & 1.71 & 11.78 \\
\hline Amount & & & \\
\hline
\end{tabular}

The distribution and composition of individual organic compounds in DOM (dissolved organic matters) are summarized in Table 6. The GC/MS chromatogram of DOM from therapeutic mud in Lake Noot is shown in Fig. 3.

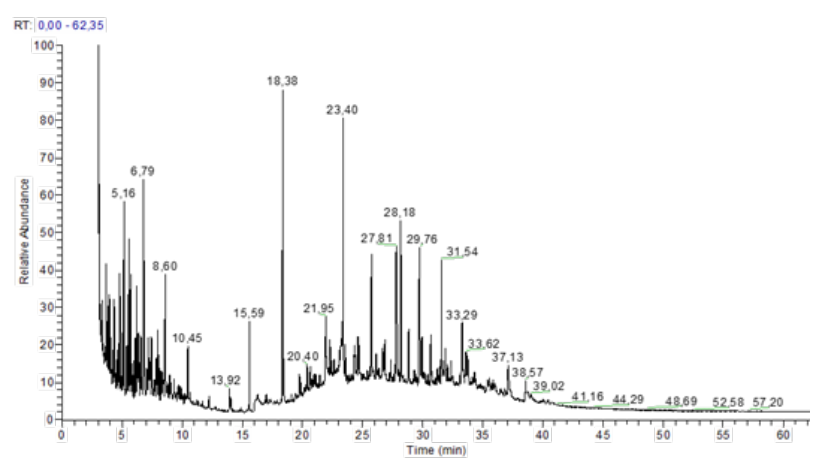

Fig. 3. Chromatogram of free organic matters

A total of 172 compounds were identified in DOM. The main group of the identified compounds in therapeutic mud alkanes (straight-chained, branched, or cyclic alkanes) and other members of the homologous series such as alkenes, ketones, aldehydes, and alcohols, accounting for $48.48 \%$ of the total composition (172 compounds) (Table 6). The next significant fraction of compounds are fatty acids, which account for $5.13 \%$ of the total composition. Within this group, the main organic compounds identified were palmitoleic $(\mathrm{C} 16: 1)$, palmitic (C16:0), oleic (C18:1), and octadecatrienoic (C18:2) acids.Carboxylic acids are common in organisms and derive mainly from animal and plant internal lipid components, such as essential oils of terrestrial plants, pheromones, and other biomolecules [17]. These fatty carboxylic acids have also been reported to act as antioxidants and membrane regulators in their isolated form and show significant anti-inflammatory activity [18].
Table 6. The composition of dissolved organic matters

\begin{tabular}{|c|c|}
\hline $\begin{array}{l}\text { Compounds in total } \\
\text { organic extract }\end{array}$ & Content, \% (in dry mass of extract ) \\
\hline $\begin{array}{l}\text { Saturated } \\
\text { hydrocarbon }\left(\mathrm{C}_{\mathrm{n}} \mathrm{H}_{2 \mathrm{n}+2}\right)\end{array}$ & $\begin{array}{l}10.28<\mathrm{C}_{13} 1.61\left(\mathrm{C}_{14}-\mathrm{C}_{17}\right) \\
10.87\left(\mathrm{C}_{26}-\mathrm{C}_{27}\right) 3.21 \mathrm{C}_{44}\end{array}$ \\
\hline $\begin{array}{l}\text { Unsaturated } \\
\text { hydrocarbon }\left(\mathrm{C}_{\mathrm{n}} \mathrm{H}_{2 \mathrm{n}}\right)\end{array}$ & $0.22<C_{13} 0.14 C_{20} 3.97 C_{35}$ \\
\hline $\begin{array}{l}\text { Carboxylic acids and } \\
\text { their ether } R C(O) O R^{1} \\
\left(R ; R^{1}\right)\end{array}$ & $\begin{array}{l}\text { 0.15 }\left(\mathrm{C}_{15} \mathrm{H}_{22} ; \mathrm{H}\right) 1.17\left(\mathrm{C}_{15} \mathrm{H}_{31} ; \mathrm{H}\right) \\
2.97\left(\mathrm{C}_{17} \mathrm{H}_{29} ; \mathrm{H}\right) 0.84\left(\mathrm{C}_{17} \mathrm{H}_{33} ; \mathrm{H}\right) \\
1.52\left(\mathrm{CH}_{3} ; \mathrm{C}_{12} \mathrm{H}_{25}\right) 0.16\left(\mathrm{CH}_{3} ; \mathrm{C}_{13} \mathrm{H}_{27}\right) \\
1.14\left(\mathrm{CH}_{3} ; \mathrm{C}_{14} \mathrm{H}_{28}\right) 0.78\left(\mathrm{C}_{2} \mathrm{H}_{2} ; \mathrm{C}_{14} \mathrm{H}_{28}\right) \\
0.21\left(\mathrm{C}_{2} \mathrm{H}_{4} ; \mathrm{C}_{18} \mathrm{H}_{37}\right) 1.08\left(\mathrm{C}_{5} \mathrm{H}_{11} ; \mathrm{CH}_{3}\right) \\
0.2\left(\mathrm{C}_{15} \mathrm{H}_{22} ; \mathrm{CH}_{3}\right) 0.24\left(\mathrm{C}_{15} \mathrm{H}_{29} ; \mathrm{C}_{18} \mathrm{H}_{37}\right) \\
0.94\left(\mathrm{C}_{15} \mathrm{H}_{29} ; \mathrm{C}_{20} \mathrm{H}_{41}\right) 1.09\left(\mathrm{C}_{17} \mathrm{H}_{33} ; \mathrm{C}_{18} \mathrm{H}_{37}\right) \\
0.3\left(\mathrm{C}_{17} \mathrm{H}_{33} ; \mathrm{C}_{20} \mathrm{H}_{39}\right) 1.21\left(\mathrm{C}_{17} \mathrm{H}_{33} ; \mathrm{C}_{20} \mathrm{H}_{41}\right)\end{array}$ \\
\hline $\begin{array}{l}\text { Dialkyl phthalates } \\
\mathrm{C}_{6} \mathrm{H}_{4}(\mathrm{COO})_{2} \mathrm{RR}^{1} \\
\left(\mathrm{R} ; \mathrm{R}^{1}\right)\end{array}$ & $\begin{array}{l}0.35\left(\mathrm{C}_{4} \mathrm{H}_{9} ; \mathrm{C}_{14} \mathrm{H}_{29}\right) 0.47\left(\mathrm{C}_{4} \mathrm{H}_{9} ; \mathrm{C}_{4} \mathrm{H}_{9}\right) \\
2.38\left(\mathrm{C}_{8} \mathrm{H}_{17} ; \mathrm{C}_{8} \mathrm{H}_{17}\right)\end{array}$ \\
\hline Alcohol & 9.08 \\
\hline Element sulfur & 6.59 \\
\hline $\begin{array}{l}\text { Halogen bearing } \\
\text { hydrocarbons }\end{array}$ & 3.96 \\
\hline Cyclic hydrocarbons & 7.58 \\
\hline Aldehyde & 0.61 \\
\hline Ketone & 0.91 \\
\hline $\begin{array}{l}\text { Aromatic } \\
\text { hydrocarbons }\end{array}$ & 5.53 \\
\hline $\begin{array}{l}\text { Nitrogen-containing } \\
\text { hydrocarbons }\end{array}$ & 3.75 \\
\hline $\begin{array}{l}\text { Sulfur-containing } \\
\text { hydrocarbons }\end{array}$ & 3.06 \\
\hline $\begin{array}{l}\text { Oxygen-containing } \\
\text { compounds }\end{array}$ & 0.75 \\
\hline Steroids & 3.34 \\
\hline Terpenes & 6.22 \\
\hline Unknown & 1.02 \\
\hline Sum & 99.9 \\
\hline
\end{tabular}

Note: ${ }^{1}$ halogen bearing hydrocarbons ${ }^{2}$ Cyclic hydrocarbons ${ }^{3}$ Aldehyde ${ }^{4}$ Ketone ${ }^{5}$ Aromatic hydrocarbons ${ }^{6}$ nitrogen-containing hydrocarbons ${ }^{7}$ sulfur-containing hydrocarbons ${ }^{8}$ oxygen-containing compounds ${ }^{9}$ steroid ${ }^{10}$ terpenes ${ }^{11}$ unknown

Table 7. Bioactive compounds identified in DOM

\begin{tabular}{|c|c|c|c|}
\hline Compound & $\begin{array}{l}\text { Mw } \\
(\mathrm{g} / \mathrm{mol})\end{array}$ & $\begin{array}{l}\text { Molecular } \\
\text { formula }\end{array}$ & $\begin{array}{l}\text { Biological } \\
\text { activity }\end{array}$ \\
\hline n-Hexadecanoic acid & 256 & $\mathrm{C}_{16} \mathrm{H}_{32} \mathrm{O}_{2}$ & Antibacterial \\
\hline Decane, 4-methyl & 156 & $\mathrm{C}_{11} \mathrm{H}_{24}$ & Antidermatitic \\
\hline 17-Pentatriacontene & 490 & $\mathrm{C}_{35} \mathrm{H}_{70}$ & $\begin{array}{l}\text { Antibacterial, } \\
\text { antiviral }\end{array}$ \\
\hline $\begin{array}{l}\text { Octadecane, 3-ethyl- } \\
\text { 5-(2-ethylbutyl) }\end{array}$ & 366 & $\mathrm{C}_{26} \mathrm{H}_{54}$ & $\begin{array}{l}\text { Antimicrobial, } \\
\text { antifungal }\end{array}$ \\
\hline Ethyl iso-allocholate & 436 & $\mathrm{C}_{26} \mathrm{H}_{44} \mathrm{O}_{5}$ & $\begin{array}{l}\text { Anti- } \\
\text { inflammatory, } \\
\text { anticancer, } \\
\text { antimicrobial, } \\
\text { antiasthma }\end{array}$ \\
\hline Heptacosane & 380 & $\mathrm{C}_{27} \mathrm{H}_{56}$ & Antimicrobial \\
\hline $\begin{array}{l}\text { Hexadecanoic acid, } \\
\text { 1-(hydroxymethyl)- } \\
\text { 1,2-ethanediyl ester }\end{array}$ & 568 & $\mathrm{C}_{35} \mathrm{H}_{68} \mathrm{O}_{5}$ & Antimicrobial \\
\hline $\begin{array}{l}\text { 7,8-Epoxylanostan- } \\
\text { 11-ol, 3-acetoxy }\end{array}$ & 502 & $\mathrm{C}_{32} \mathrm{H}_{54} \mathrm{O} 4$ & $\begin{array}{l}\text { Antimicrobial, } \\
\text { anti-inflammatory }\end{array}$ \\
\hline
\end{tabular}


Another group of organic compounds comprised terpenoids and steroids, which accounted for $9.56 \%$ of the total composition, and it is derived from plant sources.

DOM has contained dialkyl phthalates $3.2 \%$, element sulfur $6.59 \%$, sulfur-containing hydrocarbons $3.06 \%$, and oxygen-containing compounds $0.75 \%$, respectively. Previous studies and research identifies some of the identified organic compounds that have been reported in this paper as biological activities such as antimicrobial, anti-inflammatory, antibacterial, and antifungal (Table 7) [19, 20].

Therefore, it can be suggested that the therapeutic properties of muds from the lake Noot is related with the presence of the biological active compounds in DOM.

\section{CONCLUSIONS}

The general characteristics and organic matters of therapeutic mud from Lake Noot in Mongolia were investigated. The studied therapeutic muds were a pasty mass of dark gray color with a light smell of hydrogen sulfide; had a density of $1.33-1.40 \mathrm{~g} / \mathrm{cm}^{3}$, the moisture of $39.56-40.38 \%, \mathrm{H}_{2} \mathrm{~S}$ of $0.09-0.12 \%$, total organic carbon of $8.3-8.5 \%$, respectively. This therapeutic mud belongs to the hydrosulfide sticky mud type according to the classification by Malakhov and Ivanov. The total organic matter was $14.44 \%$ in dry weight. TOM contained humic substance $42.17 \%$, lipid $16.62 \%$, and carbohydrate $7.13 \%$, respectively. Dissolved organic matter in chloroform was analyzed using the gas chromatography-mass spectrometry (GC/MS) method, and then 172 compounds were identified in the therapeutic mud. The DOM composition dominated saturated and unsaturated hydrocarbons with 13 - 44 carbon atoms and carboxylic acids and their ethers. Bioactive compounds identified in the Lake Noot's mud could stand therapeutic properties of this mud.

\section{REFERENCES}

1. Quintela A., Terroso D., Ferreira Da Salva E., Rocha F. (2012) Certification and quality criteria of peloids used for therapeutic purposes. Clay minerals, 47(4), 441-451.

http://dx.doi.org/10.1180/claymin.2012.047.4.04

2. Carretero M.I. (2020) Clays in pelotherapy. A review. Part I: Mineralogy, chemistry, physical and physicochemical properties. Appl. Clay Sci., 189(2020), 105526.

https://doi.org/10.1016/j.clay.2020.105526

3. Carretero M.I. (2020) Clays in pelotherapy. A review. Part II: Organic compounds, microbiology and medical applications. Appl. Clay Sci., 189(2020) 105531.

https://doi.org/10.1016/j.clay.2020.105531

4. Limnological catalog of Mongolian lakes. http://oslo.geodata.es/mongolian_lakes/index. php?page=home\&lang $=\mathrm{mn}$
5. A chemical and technological study of organic matter in the continental crust. (in Mongolian)

6. Tserensodnom J. (2000) The catalogue of Mongolian lakes. $1^{\text {st }}$ ed., Ulaanbaatar, 61 (in Mongolian).

7. Bakhman V.I., Ovsyanikova K.A. (1965) Methods for healing mud analyses. Nauka, Moscow,12-63 (in Russian).

8. Baatar R. (2003) The methods for determination of chemical, agrochemical, water-physical properties and characteristics of soils. Ulaanbaatar, 85 (in Mongolian).

9. Voronkov M.G., Dolmaa G., Tserenpil Sh., Ganzaya G., Abzaeva K.A. (2009) Chemical composition of peloids from Gurvan Nuur Middle Lake. Doklady Chemistry, 426, 115-117. https://doi.org/10.1134/S0012500809060019

10. Tserenpil Sh., Dolmaa G., Voronkov M.G. (2010) Organic matters in healing muds from Mongolia. Appl. Clay Sci., 49(1-2), 55-63. https://doi.org/10.1016/j.clay.2010.04.002

11. Tserenpil Sh. (2005) Chemical composition and organic composition of therapeutic mud in some deposits of Mongolia. Ph.D thesis, Mongolian University of Science and Technology, Mongolia

12. Ivanov B.B., Malakhov L.M. (1963) Materials on studies of peloids. Mir, Moscow, 68 (in Russian).

13. Rudnick R.L., Gao S. (2003) The composition of the continental crust. Treatise on Geochemistry, 3, 1-64. http://dx.doi.org/10.1016/b0-08-043751-6/03016-4

14. Tserenkhand B., Badnainymbuu Z. (2016) Composition and classification of some peloids in the western region of Mongolia. Journal of Chemical Technology and Metallurgy, 5, 570-576. https://dl.uctm.edu/journal/web/j2016-5

15. Neli G., Maria, L.M., Carmen P.G., Jose L.L., Nastja R.S., et al. (2017) The mineralogical, geochemical, and thermophysical characterization of healing saline mud for use in pelotherapy. Appl. Clay Sci., 135(2017), 119-128. https://doi.org/10.1016/j.clay.2016.09.013

16. Suarez M., Gonzalez P., Dominguez R., Bravo A., Melian C., et al. (2011) Identification of organic compounds in San Diego de los Banos peloid. The Journal of Alternative and Complementary Medicine, February, 17(2), 155-165. https://doi.org/10.1089/acm.2009.0587

17. Rushdi A.I., Kassim T, Simoneit BRT. (2009) Organic tracers in sediments from the coastal zone of Ras Abu el-Darag, Gulf of Suez. Environ. Geol., 58, 1675-1687. https://doi.org/10.1007/s00254-008-1668-3

18. Centini M., Tredici M.R., Biondi N., Buonocore A, Maffei Facino R, Anselmi C. (2015) Thermal mud maturation: organic matter and biological activity. Int. J. Cosmet. Sci., 37, 339-347. https://doi.org/10.1111/ics.12204 
19. Zekeya N., Chacha M., Shahada F., Kidukuli A. (2014) Analysis of phytochemical composition of Bersamaabyssinica by gas chromatography mass spectrometry. Journal of Pharmacognosy and Phytochemistry, 3(4), 246-252.
20. Nguyen T.B., Phan V.H., Cao N.D. (2018) Bioactive compounds from marine fungus Penicillium citrinum Strain ND7c by gas chromatographymass spectrometry. The Pharm. Chem. Journal, $\mathbf{5}(1), 211-224$ 